\title{
ATTITUDES OF IN-SERVICE PHYSICAL EDUCATORS TOWARD TEACHING CHILDREN WITH PHYSICAL DISABILITIES IN GENERAL PHYSICAL EDUCATION CLASSES IN CYPRUS Ioanna Fournidou*, Martin Kudlacek**, Christina Evagellinou***
}

* EMMAPA MSc. studies at Faculty of Kinesiology and Rehabilitation Sciences, Catholic University, Leuven, Belgium

** Palacky University, Olomouc, Czech Republic

*** Department of Physical Education and Sport Sciences at Serres, Aristotle University of Thessaloniki

Over the last two decades the idea of inclusion of students with special educational needs (SEN) in general schools has become increasingly the focus of Inclusive education in Cyprus. The passage of new laws mandating school inclusion, the new educational physical education curriculum as well as the attention that has been given to physical education teachers' training, are significant changes towards school inclusion. The aim of this study was to identify the attitudes, and predictors of attitudes, of in service Cypriot secondary school physical education teachers towards the inclusion of students with physical disabilities in general physical education (GPE) classes. The Greek translated version of the questionnaire ATIPDPE-GR (Doulkeridou, Evaggelinou \& Kudlacek, 2010) originally developed by Kudlacek, Valkova, Sherrill, Myers and French (2002) was used. The instrument was designed based on the "Theory of Planned Behavior" (TPB) by Ajzen (1991). Statistical analysis included one way analysis of variance (ANOVA). Stepwise multiple regression demonstrated the percentage of variability of variance of intention as explained by the Attitude Toward Behavior and Perceived Behavioral Control subscales (R Square =0,547). The Perceived Behavioral Control had the strongest correlation on intention to include students with physical disabilities in general Physical Education $(\mathrm{p}<0.01)$. The subscale Attitude toward Behavior had the second strongest correlation on intention to include students with physical disabilities in general Physical Education $(\mathrm{p}<0.05)$. In addition, results show no significant difference between females and males towards intention for inclusion.

KEYWORDS: attitudes, inclusion, physical educators, physical education, students with disabilities and SEN, physical disability

\section{INTRODUCTION}

Inclusion is the philosophy that students should be educated together in one classroom instead of separate classrooms designated to meet special needs. Inclusion is defined as the education of all children with disabilities (mild to severe) in regular education even if special resources are needed to make it effective (Block \& Vogler, 1994). According to Sherrill (2004), exceptions to this practice may include individuals with severe to profound retardation and/or multiple disabilities that would make success in the classroom of a regular school very difficult or impossible. Regarding physical education,
"Inclusion is the practice of placing many different kinds of students in general physical education and in this environment general physical education teachers will make the necessary changes in didactics, pedagogy, and curriculum to assure that all students will achieve their physical education goals and feel safe, happy, comfortable, and successful in the physical education setting"' (Kudlacek, 2001, p. 190).

The ideal educational setting for any student is that of a less restricted environment (LRE) where a particular student will benefit the most. "A least restrictive environment is one in which students with disabilities are 
educated with their typically developing peers to the maximum extent possible" (Lieberman, James \& Ludwa, 2004). According to Stein (1994) the child should always remain the center of focus when discussing placement decisions. "In their zest to promote inclusion, many inclusionists forgot about the child" (Block, 1999). Inclusion in general schools has many benefits both for students with and without disabilities. For example, Mrug and Wallander (2002) pointed out that students with SEN have the same possibilities and opportunities to participate as their nondisabled counterparts in school and social events. Students without disabilities learn to approach children with disabilities in a more welcoming manner (Romer \& Haring, 1994), develop empathy and acceptance of individuals' differences (Lieber, Capell, Sandal, Wolfberg, Horn \& Bechman, 1998), become more aware and more responsive to other children's needs (Peck, Carlson \& Helmstetter, 1992), and learn more about people with a disability (Horvat,1990). Finally, inclusive education provides the opportunity for the cultivation of positive attitudes of students without disabilities toward peers with SEN (Hall, 1994; Mrug \& Wallander, 2002; Salisbury, Callucci, Palombaro \& Peck, 1995).

Regarding the improvement of physical education and sports status within all European Union (EU) countries, there is a common policy among them referring as "Recommendation $\operatorname{Rec}(2003) 6$ of the Committee of Ministers to member states for children and young people, including of course students with special needs" (Kudlacek, 2009). Cyprus joined the EU in 2004.

The trend towards inclusionary programs in Cyprus was first noted back in the 1980s (Ministry of education and culture, 1996). It wasn't until 1987-88 that services of special education for 350 children with SENs in the mainstream public schools were formally provided. The Cypriot State has shown that it has fully accepted the philosophy of inclusion, by passing laws $3340 / 1999$ and $3497 / 2001$, which is related to the education of children with SEN in public schools (Ministry of education and culture, 2001). The government has the obligation to serve the students in either general or special education classes or to ensure the provision of education in other settings such as home and hospitals. The responsibility for the type of education and support that each child will have falls on the Provincial Committee. This committee coordinates the involvement of all involved institutions so as to ensure that the child with SEN will receive the appropriate support.

The Cypriot Ministry of Education and Culture recently published the National Curriculum for Physical Education (2010) with respect to the inclusion of children with SEN in physical education classes. The curriculum states that special attention should be given to the inclusion of students with SEN in general schools, ranging from preschool age right through secondary school. Furthermore, it suggests that special adjustments should be made in physical education classes for the development of motor skills and positive attitudes of all children towards physical education (Ministry of education and culture, 2010a).

Though the curriculum is targeted towards the inclusion of students with SEN, it does not provide specific programs or lesson plans to guide physical educators on how to adapt their educational plans to students with specific physical disabilities. Thus it is crucial that the Cypriot Ministry of Education take into consideration how adapted physical educators and general physical educators impact students' learning when making changes in physical education and inclusion of pupils with SEN. Angelides, Stylianou, and Gibbs (2006) investigated how elementary school teachers were prepared for inclusive education in Cyprus. Findings indicated that certain factors related to the curricula, can be considered as barriers in the development of inclusive practices by student teachers. Such barriers primarily dealt with teachers' attitudes and approaches to the idea of inclusion. Teachers tended to think on the basis of the medical and charity models, 
favouring special schooling for specific groups of children rather than inclusion. By contextualizing teacher training courses to suit teachers' prior knowledge, attitudes and beliefs about inclusion, teachers' were better equipped to help individuals with special needs and more likely to make their classrooms inclusion-friendly.

Attitude is defined as: "The idea charged with emotions which predisposes a class of actions to a particular class of social situations" (Triandis, 1971, p.2). This definition includes the three components (cognitive, affective and behavioral attributes) typically identified with attitudes towards disability (Antonak \& Livneh, 1988). The most updated theory of changing attitudes towards individuals with SEN is the Theory of Planned Behaviour (TPB). At the centre of the Theory of Planned Behavior lies the individual's intention. According to Ajzen (1991), the stronger the intention to engage in a particular behaviour, the higher the probability for that behaviour to occur will be. The author takes into consideration many factors that might trigger a person to act in a certain way. One such factor is whether the person believes he or she has control over the situation or not (perceived behavioural control). If the task seems difficult and the person perceives many obstacles keeping him or her from achieving his or her goal, then he or she will be less likely to act in the desired way. An equally important factor is attitude, negative or positive, including subjective norms such as our beliefs of how others want us to behave. Ajzen's theory of behaviour states that the outcome is a result of certain preconditions: attitude, subjective norm and perceived behavioural control. These three predict whether the person arrives or not at intention (motivation) to behave in a certain way. Many studies show that there is a direct relationship between attitudes, subjective norms and intention and consequently with behaviour.

Within the framework of adapted physical education and inclusion in school, and specifically in physical education (PE), the Theory of Planned Behaviour can be operationalized as follows: Teachers with positive attitudes towards inclusion, stronger subjective norms and higher perceived behavioural control are more likely to have stronger intention to practice inclusion and consequently demonstrate more "inclusive" behaviour (Ajzen \& Driver, 1992). Many studies have begun to help both general and adapted physical educators (APE) understand what is needed to make inclusion in General Physical Education (GPE) successful. GPE teachers without the support from an APE specialist or teacher assistant (TA) can include a student with SEN in GPE without negatively impacting the learning of peers without disabilities (Obrusnikova et al., 2003).

Attitudes towards inclusion in PE have an important role in the smooth and successful progression of inclusion and the positive outcomes. Hegarthy (1994) and Pumfrey (2000) particularly indicated the important role of teachers' attitudes in the success or failure of inclusion of SEN students into mainstream classrooms because they can influence the children of their class, their colleagues or the parents of their students.

Inclusion produces many benefits however can be significantly detrimental if not implemented appropriately and with careful consideration to all students, including students with SEN. On the other hand, gender and the type of disability significantly influences attitudes towards students with SEN. Students without disabilities in integrated GPE had significantly less positive attitudes towards peers with physical disabilities and significantly more positive attitudes towards peers with behavioural disabilities as compared to students in segregated GPE (O'Brien et al., 2009; Bartonova, Kudlacek \& Bressan, 2007; Martin \& Kudlacek, 2010).

Gender and age are considered to be variables that significantly influence attitudes of general physical education teachers. Women have been shown to have more favorable attitudes than men towards students with SEN (Hodge \& Jansna, 1999, Hutzler et 
al, 2005; Downs \& Williams, 1994). However, this is not a consistent finding as others have found no significant gender differences (Hodge et al, 2002; Rizzo \& Vispoel, 1991). DePauw and Goc Karp (1990) found that older physical educators possess less positive attitudes than their younger counterparts, but other studies revealed no relationship between attitudes and age of physical educators (Rizzo \& Vispoel, 1991; Rizzo \& Wright, 1988). Attitudes of physical educators are more likely to be positive when they have more academic preparation (Folsom-Meek \& Rizzo, 2002; Kowalski \& Rizzo, 1996; Block \& Rizzo, 1995; Rizzo \& Kirkendall, 1995), experience in teaching students with disabilities (Kozub \& Poretta, 1998, Block \& Rizzo, 1995, Schmidt-Gotz et al, 1994) and higher perceived competence in teaching students with disabilities (Kowalski \& Rizzo, 1996, Block \& Rizzo, 1995, Rizzo \& Kirkendall, 1995, Schmidt-Gotz et al, 1994).

Research in the area of attitudes of physical education teachers in Greece towards inclusion of students with disabilities in GPE classes started recently. According to Vaporidi, Kokaridas, and Krommidas, (2005) the physical educators' contribution towards inclusion of students with SEN in general class is related to the level of knowledge that the teachers believe they have regarding the disability condition. However, in this study the encouraging fact is that the participants showed willingness to broaden their knowledge about the education of people with disabilities. Papadopoulou, , Kokaridas, , Papanikolaou, and Patsiaouras, (2004) confirmed the aforementioned findings, and added that physical educator's believed that inclusion could be successful with the appropriate support services.

These findings provide a first look at Greek physical education teachers' attitudes towards inclusion. In the past, physical education teachers teaching in Cyprus had been educated in Greek Universities earning a degree from the Departments of Physical Education. Rapid changes in both countries have been noted over the last five years including extra courses in the school curriculum (Olympic/Paralympic Education), and the organization of several seminars and sports events for individuals with SEN. According to Hardman (2008), Cyprus is considered to be one of the countries with limited provisions for programs in adapted physical education. However, the current government policy is encouraging and supporting the integration of students into the ordinary school system, which indicates that schools need to be organized in ways that provide equal opportunities for teaching and learning of all children (Ministry of education and culture, 2010b).

In an attempt to study the Cypriot educators' attitudes, Batsiou, Bebetsos, Panteli and Antoniou (2006) revealed that elementary school teachers had more experience in working with SEN pupils, though had very limited education in the subject of Special Education at the university level. However, substantive long-term training in the formation of positive teacher attitudes towards inclusion has also been found to be a significant factor. The attitudes of current physical education teachers are very important and should be taken into consideration when making changes as they can have a direct impact on the success of students' learning (Meegan \& MacPhail, 2006).

The purpose of this study was to identify the attitudes and predictors of attitudes, of inservice Cypriot secondary physical education teachers towards the inclusion of students with physical disabilities in general physical education classes.

\section{METHODS \\ Participants}

The total number of in-service PE teachers in Cyprus presently teaching at the secondary level is four hundred and twenty one (421). Participants in the current study included one hundred in-service PE teachers randomly selected from secondary schools all over unoccupied Cyprus. Out of the 100 participants, forty seven (47) were women 
with an average age of 47.21 years and an average of 14.94 years teaching PE. In addition, 53 participants were men with an average age of 49.77 years and an average of 10.32 years teaching PE. The collection of data was completed during the second semester of 2010 and the questionnaires represent a corresponding percentage from four districts. All participants held at least a bachelor's degree in Physical Education, accredited by the Cypriot Ministry of Education, and attended seminars delivered by the Pedagogical Institute which is under the Cyprus Ministry of Education, during their first year of teaching.

\section{Instrument}

The Greek version of the questionnaire "Attitudes toward Teaching Individuals with Physical Disabilities in Physical Education" (ATIPDPE-GR) (Doulkeridou, Evaggelinou \& Kudlacek, 2010) was used for this study. In this study the instrument was used to measure the attitudes of in-service Cypriot physical educators towards inclusion of students with physical disabilities in general physical education classes. The original ATIPDPE was developed by Kudlacek, Valkova, Sherrill, Myers and French (2002) in the Czech language.

The questionnaire starts with the purpose of the survey, general instructions for completing the questionnaire and an example for using the rating scale while answering an item. Part I and II of the survey is comprised of items related to the level of understanding of the definitions. Part I consists of the definition of students with physical disabilities (PD) described as: students (6-18 yrs) diagnosed as having one of the following disabilities (cerebral palsy, amputations, spina bifida, muscular dystrophy etc.) Students might be able to walk without assistive devices, or might be using mechanical or power wheelchairs, canes, walkers, or other assistive devices. These students might need an individual approach and the help of an assistant. Part II consists of definitions of inclusion. Part III is the main part of the questionnaire which is constructed in a way to include items related to intention statements (4), behavioural beliefs (12), normative beliefs (7) and control beliefs (8). The 7-point Likert scale was used for all items of the survey: 1 being the lowest and 7 the highest score. The three components of TBP that are posited to predict intention in the ATIPDPE questionnaire are the attitude toward behaviour, subjective norm and perceived behavioural control. In addition, the ATIPDPE instrument measures three psychological components: a) positive outcome for students, b) negative outcome for students, and c) negative outcome for teachers. Enclosed with the questionnaire was a participant information sheet requesting personal information as well as information related to previous experience with individuals with disabilities and previous training related to Adapted Physical Activity (APA).

\section{Data Collection}

The questionnaire was distributed and collected by the schools' vice-principle to an equal distribution according to the percentage of secondary Physical education teachers. The equal distribution was based on the fact that according to the numbers of secondary PE teachers working in each district, the equal distribution of questionnaires were distributed and collected. According to the schools and the teachers in each district included, the same percentage of questionnaires was collected. All responses were anonymous for unbiased and more honest responds.

The scoring system required the use of a 7-point scale for one construct and a -3 to +3 scale for the other construct. Specifically, behavioural belief evaluation scores, normative belief strength scores, and control belief power scores were transformed using the SPSS PC11.0 from unidirectional $(1,2,3$, $4,5,6,7)$ to bidirectional $(-1,-2,-3,0,+1$, $+2,+3)$ scoring in accordance with th guidelines for the Theory of Planned Behaviour as given by Ajzen (1991). Scores for each statement were then multiplied to create item belief scores; likelihood $\mathrm{x}$ 
evaluation, belief strength $\mathrm{x}$ motivation, and belief strength $x$ belief power (LxE, BSxMC, and BSxBP) (Kudlacek et al, 2002).

\section{Data Analysis}

To compare the attitudes between the in-service PE teachers from Cyprus in relation to gender, a one way analysis of variance (ANOVA) was used. Software package SPSS 11.0 was used to determine if there were any significant differences between PE teachers in relation to their attitudes, subjective norm, perceived behavioural control and intention to include students with physical disabilities in GPE classes. The level of significance was set at 0.05 . Analysis was also carried out on the 12 individual belief statements, the 7 normative belief statements, and the 8 control belief statements, comparing responses between genders of in-service PE teachers. Stepwise multiple regression analysis was used to determine the influence of attitudes, perceived behavioural control and subjective norms on intention to include students with physical disabilities in physical education.

\section{RESULTS}

With regards to the demographic questions, included at the end of the questionnaire, participants replied with the following responses. $87.2 \%$ of females and $79.2 \%$ of males had personal experiences with individuals with physical disabilities. Correspondingly according to the above percentages, females rated the experience as: $8.5 \%$ not good, $40.4 \%$ satisfactory, $36.2 \%$ very good and $2.1 \%$ outstanding. Males rated the experience as: $3.8 \%$ not good, $50.9 \%$ satisfactory, $20.8 \%$ very good and $3.8 \%$ outstanding. Eight out of 47 females had an APA course in their university curricula representing $19.1 \%$ of total female sample. Seven of them had an APE course and one had special needs education course. Likewise eight out of 53 male had an APE course in their university curricula representing $15.1 \%$ of total male sample. Seven out of 47 females and 14 out of 53 men received information

during the university years related to physical education and sport of individuals with physical disabilities. Courses taken during their study years included APE course, education for deaf population course, Olympic and Paralympic education, as well as student teaching course for females, and APE course and special needs education for males.

Eighteen out of 47 females and 21 out of 53 men received information outside their university studies related to APE and sport of individuals with physical disabilities. Females listed the following sources: EUPEA seminar, experience from the Paraskevaides Institution (special school), Cyprus pedagogic institute, seminar from the Cypriot ministry of Ed., mass media, textbooks of Olympic and Paralympic education as a new subject taught in PE high school, and from watching Paralympics. Males listed the following sources: Cyprus Pedagogic Institute seminar, sport seminar, experience from national Paralympic team, experience from the Institute of Steliou Ioannou (special School), textbooks of Olympic and Paralympic education as a new subject taught in PE high school, from watching international games and Paralympics. The following answers were reported in response to the question, "How confident do you feel today teaching PE to students with physical disabilities?" Out of forty seven females ten reported not confident at all, thirty two reported somewhat confident, and five reported very confident. Males responded to the same question very similarly. Out of fifty-three men ten reported not confident at all, thirty-eight reported somewhat confident, and five reported very confident. In contrast to the previous question, the following answers were reported in response to the question "How confident do you think you will feel teaching PE to students with physical disabilities, if you receive specific training and didactics course?" Out of 47 females three reported not confident at all, 17 reported somewhat confident, and 27 reported very confident. Males responded to the same question with more positive results. Out of 53 men two reported not confident at all, 17 reported somewhat confident, and 44 reported very confident. 
The results from the stepwise multiple regression indicated the $\mathrm{R}$ Square to be 0.55 showing the percentage of variability of variance of intention explained by the Attitude toward Behaviour and Perceived Behavioural Control. The Perceived Behavioural Control had the strongest correlation on intention to include students

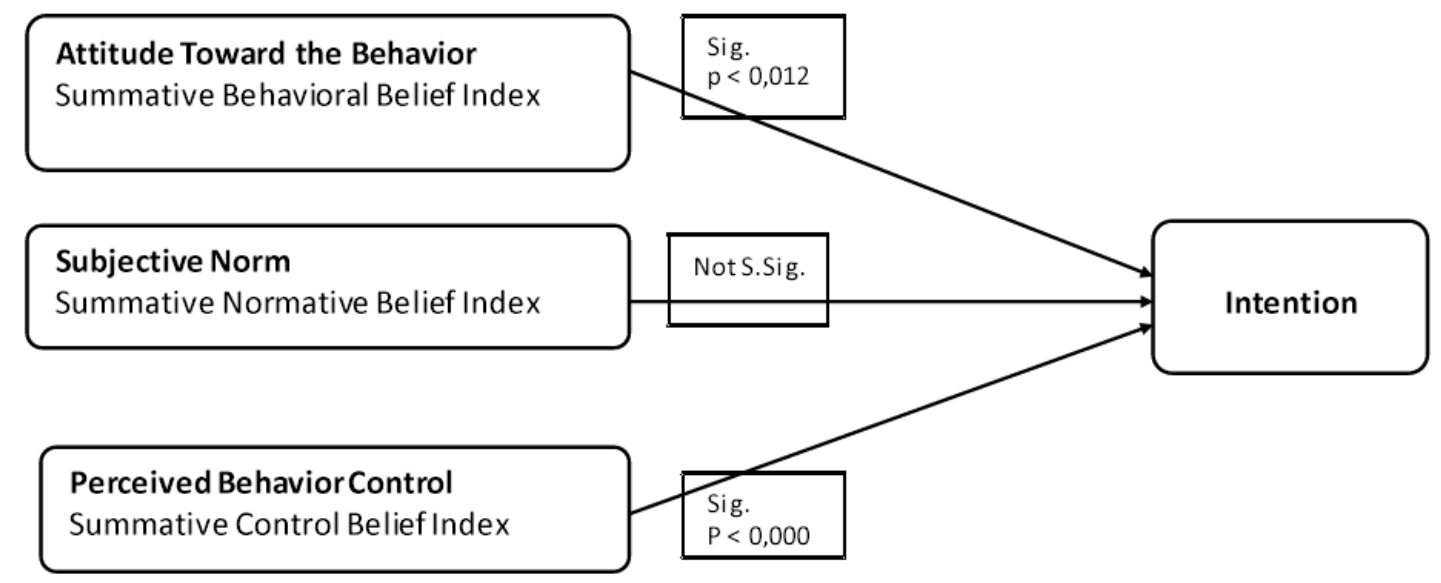

Figure 1. Expected correlation between subscales of ATIPDPE

Based on the intention statements results the males had higher results than females on intention to include students with physical disabilities in their general PE classes. The results showed no statistically significant $(p$ $>.05)(0.21)$ difference between females and males towards intention for inclusion of students with physical disabilities in general PE classes. Mean score for females was 19.11 $(\mathrm{SD}=6.60)$. On the other hand, mean score for males was $20.94(\mathrm{SD}=7.80)$. With the middle score at 16 and higher at 28 both females and males were above middle score but not close maximum.

Behaviour belief is the TPB component that is used to infer attitude with physical disabilities in general PE with $\mathrm{p}$ $<0.00$. Attitude toward Behaviour had the second strongest correlation on intention to include students with physical disabilities in general PE with $\mathrm{p}<0.01$. Subjective Norm shows no Statistical Significance on intention.

Table 1. Scores of female and male in-service PE teachers on Behavioral Beliefs

\begin{tabular}{|c|c|c|c|c|c|c|c|}
\hline & & & Femal & $(\mathrm{N}=47)$ & Males & $J=53)$ & \\
\hline & about outcomes & scale & $\mathrm{M}$ & SD & $\mathrm{M}$ & $\mathrm{SD}$ & Sig \\
\hline 1 & Will facilitated learning & Likelihood & 5.46 & 1.68 & 6.35 & 1.36 & \\
\hline & to interact with students & Evaluation & 1.62 & 1.60 & 2.35 & 1.32 & \\
\hline & with PD & Like x Eval & 11.14 & 8.75 & 16.66 & 7.57 & $.001 *$ \\
\hline 2 & Will make my teaching & Likelihood & 4.96 & 1.84 & 53.11 & 1.33 & \\
\hline & more difficult & Evaluation & 0.72 & 1.77 & 1.09 & 1.09 & \\
\hline & & Like x Eval & 4.04 & 9.52 & 5.92 & 6.53 & .248 \\
\hline 3 & Will encourage students & Likelihood & 5.45 & 1.44 & 6,16 & 1,41 & \\
\hline & to help others & Evaluation & 1.60 & 1.43 & 2.41 & 1.06 & \\
\hline
\end{tabular}




\begin{tabular}{|c|c|c|c|c|c|c|c|}
\hline & & Like x Eval & 10.02 & 8.86 & 15.58 & 7.79 & $.001 *$ \\
\hline \multirow[t]{3}{*}{4} & \multirow{3}{*}{$\begin{array}{l}\text { Will make lesson } \\
\text { planning and preparation } \\
\text { much more difficult }\end{array}$} & Likelihood & 5.49 & 1.61 & 5.09 & 1.55 & \\
\hline & & Evaluation & 0.85 & 1.53 & 1.07 & 1.41 & \\
\hline & & Like x Eval & 5.70 & 7.60 & 5.64 & 7.81 & .969 \\
\hline \multirow[t]{3}{*}{5} & \multirow{3}{*}{$\begin{array}{l}\text { Will teach great } \\
\text { great tolerance }\end{array}$} & Likelihood & 5.55 & 1.28 & 6.13 & 1.48 & \\
\hline & & Evaluation & 2.00 & 1.00 & 2.16 & 1.40 & \\
\hline & & Like x Eval & 11.78 & 6.94 & 14.77 & 8.56 & .060 \\
\hline \multirow[t]{3}{*}{6} & \multirow{3}{*}{$\begin{array}{l}\text { Will have positive effect } \\
\text { on personalities of } \\
\text { students with PD }\end{array}$} & Likelihood & 5.34 & 1.57 & 6.01 & 1.43 & \\
\hline & & Evaluation & 1.57 & 1.52 & 2.24 & 1.24 & \\
\hline & & Like x Eval & 9.59 & 8.45 & 14.64 & 7.42 & $.002 *$ \\
\hline \multirow[t]{3}{*}{7} & \multirow{3}{*}{$\begin{array}{l}\text { Will expose students } \\
\text { with PD to } \\
\text { discrimination }\end{array}$} & Likelihood & 4.72 & 1.80 & 6.69 & 1.26 & \\
\hline & & Evaluation & -0.23 & 1.95 & -0.77 & 1.74 & \\
\hline & & Like $\mathrm{x}$ Eval & 0.06 & 10.79 & -3.94 & 9.08 & .047 \\
\hline \multirow[t]{3}{*}{8} & \multirow{3}{*}{$\begin{array}{l}\text { Will slow down } \\
\text { instruction and } \\
\text { progress }\end{array}$} & Likelihood & 5.23 & 1.61 & 4.73 & 1.35 & \\
\hline & & Evaluation & 0.08 & 1.65 & -0.56 & 1.49 & \\
\hline & & Like x Eval & 0.95 & 10.00 & -2.39 & 8.17 & .068 \\
\hline \multirow[t]{3}{*}{9} & \multirow{3}{*}{$\begin{array}{l}\text { Will improve knowledge } \\
\text { about persons } \\
\text { with disabilities }\end{array}$} & Likelihood & 5.70 & 1.28 & 6.13 & 1.47 & \\
\hline & & Evaluation & 1.89 & 1.10 & 2.15 & 1.59 & \\
\hline & & Like x Eval & 11.65 & 7.56 & 15.71 & 8.71 & .135 \\
\hline \multirow[t]{3}{*}{10} & \multirow{3}{*}{$\begin{array}{l}\text { Will teach } \\
\text { cooperation }\end{array}$} & Likelihood & 5.77 & 1.37 & 6.09 & 1.50 & \\
\hline & & Evaluation & 1.87 & 1.11 & 2.01 & 1.66 & \\
\hline & & Like x Eval & 11.91 & 7.90 & 14.24 & 9.55 & .190 \\
\hline \multirow[t]{3}{*}{11} & \multirow{3}{*}{$\begin{array}{l}\text { Will expose students } \\
\text { without PD to } \\
\text { discrimination }\end{array}$} & Likelihood & 4.55 & 2.16 & 3.98 & 1.78 & \\
\hline & & Evaluation & 0.57 & 2.01 & -0.79 & 1.91 & \\
\hline & & Like $\mathrm{x}$ Eval & 4.14 & 10.71 & -2.43 & 8.68 & $.001 *$ \\
\hline \multirow[t]{3}{*}{12} & \multirow{3}{*}{$\begin{array}{l}\text { Will reduce } \\
\text { quality } \\
\text { of lessons } \\
\end{array}$} & Likelihood & 4.13 & 1.88 & 4.05 & 1.73 & \\
\hline & & Evaluation & -0.64 & 1.94 & -1.28 & 1.63 & \\
\hline & & Like x Eval & -0.40 & 9.29 & -4.54 & 7.72 & $.017 *$ \\
\hline \multicolumn{2}{|c|}{ Total Behavioral Beliefs } & Like $x$ EvL & 80.63 & 56.26 & 89.32 & 55.22 & .439 \\
\hline
\end{tabular}

Note. Likelihood scores range from 1 to 7 (extremely unlikely outcome to extremely likely outcome). Evaluation scores range from -3 to +3 (extremely bad outcome to extremely good outcome). Like $x$ Evaluation scores range from -21 to $+21 .{ }^{*} p<.05, * * p<.01$

Normative belief is the TPB component that is used to determine subjective norm (perceived social pressure and estimated response to this pressure). Table 2 indicates in-service PE teachers' views on Normative Beliefs. Based on the findings, item 3 shows statistical significance $(\mathrm{p}<.05)$ with males reporting higher scores. These findings showed that male PE teachers demonstrated higher motivation to follow specialists' advice to include students with physical disabilities in general PE classes.

Table 2. Scores of female and male in-service PE teachers on Normative Beliefs

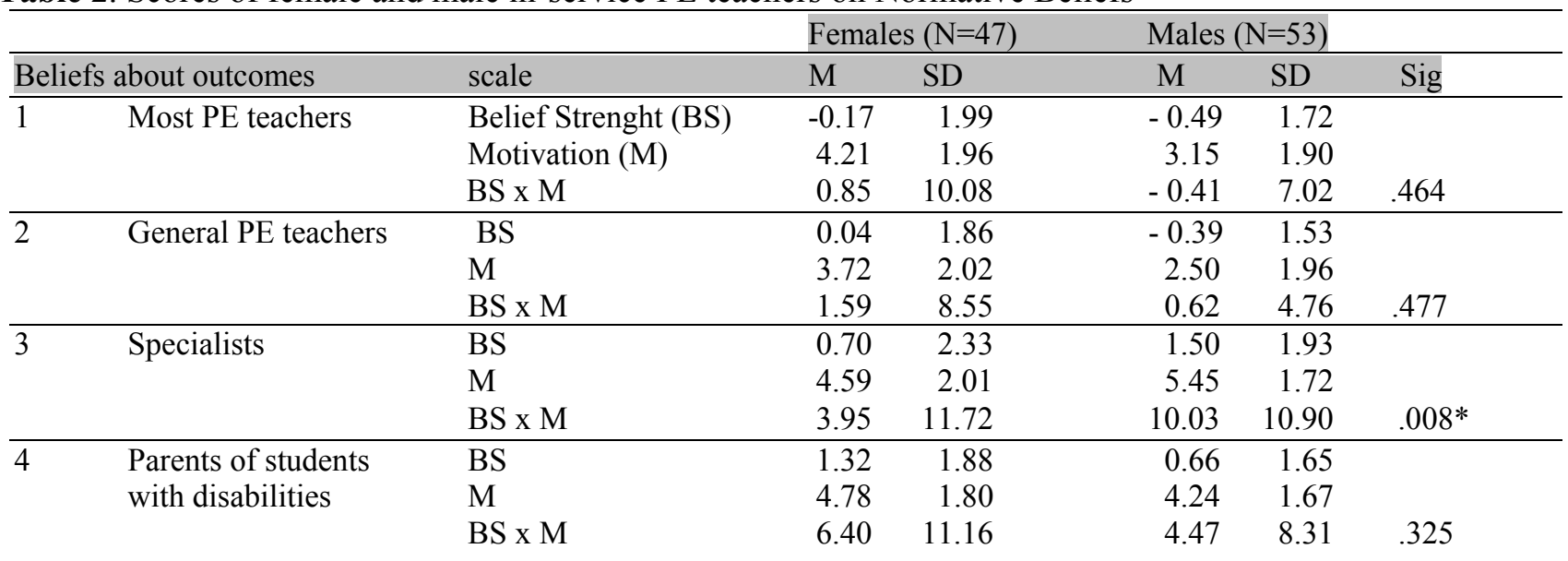




\begin{tabular}{lllrrrrr}
\hline 5 & Parents of students & BS & 0,29 & 1,81 & $-0,86$ & 1,73 & \\
& without disabilities & M & 4,19 & 1,82 & 2,50 & 1,86 & \\
& & BS x M & $-0,17$ & 9,40 & 0,11 & 5,76 &, 854 \\
\hline 6 & Students with & BS & $-0,08$ & 2,00 & 0,24 & 1,65 & \\
& disabilities & M & 4,14 & 1,91 & 2,47 & 2,03 & \\
& & BS x M & 1,31 & 9,06 & 0,90 & 6,15 &, 788 \\
\hline 7 & Principals in & BS & 0,55 & 1,96 & 0,90 & 1,55 & \\
& most schools & M & 4,25 & 2,05 & 3,00 & 1,94 & \\
& & BS x M & 4,19 & 9,16 & 2,73 & 6,16 &, 349 \\
\hline Total & Normative Beliefs & BS x M & 18,14 & 54,42 & 18,47 & 34,70 &, 972
\end{tabular}

Note. Belief strength (BS) scores range from -3 to +3 (I should not to I should). Motivation (M) scores range from 1 to 7 (not at all to very much). BS $x$ M scores range from -21 to +21 . * $p<.05$, **p $<.01$

Control belief is the TBP component that is used to determine perceived behavioural control, direct predictor of intention. On table 3 items 2, 6, and 7 show statistical significance with males reporting higher scores than females. The results indicate that males agree with the statement that schools have appropriate equipment which will make inclusion much easier. Male respondents agree that most students will show understanding and willingness to cooperate with students with PD, and they also agree that principles in most schools will support them in inclusion in PE. Additionally, the summative result score is statistically significant favouring the males.

Table 3. Scores of female and male in-service PE teachers on Control Beliefs

\begin{tabular}{|c|c|c|c|c|c|c|c|}
\hline & & & Femal & $(\mathrm{N}=47)$ & Male & $(\mathrm{N}=53)$ & \\
\hline & about outcomes & scale & $\mathrm{M}$ & $\mathrm{SD}$ & $\mathrm{M}$ & SD & Sig \\
\hline 1 & I have appropriate & Belief Strength (BS) & 3.63 & 1.92 & 3.94 & 1.52 & \\
\hline & training & Belief Power (BP) & 1.51 & 1.76 & 2.11 & 1.73 & \\
\hline & & $\mathrm{BS} \times \mathrm{BP}$ & 6.85 & 7.00 & 9.43 & 66.50 & .062 \\
\hline 2 & Schools have & $\mathrm{BS}$ & 2.04 & 139 & 2.54 & 1.38 & \\
\hline & appropriate equipment & $\mathrm{BP}$ & 0.82 & 2.10 & 2.15 & 1.68 & \\
\hline & & $\mathrm{BS} \times \mathrm{BP}$ & 1.65 & 5.16 & 5.83 & 4.50 & $.000 *$ \\
\hline 3 & Schools have & $\mathrm{BS}$ & 5.68 & 2.09 & 5.73 & 1.86 & \\
\hline & lot of architectural & $\mathrm{BP}$ & -1.57 & 2.05 & -2.07 & 1.71 & \\
\hline & barriers & $\mathrm{BS} \times \mathrm{BP}$ & -8.31 & 13.67 & -12.35 & 11.47 & .112 \\
\hline 4 & Schools have & $\mathrm{BS}$ & 3.19 & 1.70 & 3.00 & 1.44 & \\
\hline & appropriate financial & $\mathrm{BP}$ & 1.31 & 1.94 & 2.37 & 1.25 & \\
\hline & resource & $\mathrm{BS} \times \mathrm{BP}$ & 4.85 & 6.99 & 7.11 & 4.71 & .058 \\
\hline 5 & Students are informed & $\mathrm{BS}$ & 3.25 & 1.64 & 2.35 & 1.27 & \\
\hline & about students with PD & $\mathrm{BP}$ & 1.53 & 1.41 & 2.05 & 1.39 & \\
\hline & & $\mathrm{BS} \times \mathrm{BP}$ & 4.38 & 5.95 & 4.75 & 3.97 & .712 \\
\hline 6 & Students show & $\mathrm{BS}$ & 5.46 & 1.33 & 6.03 & 1.40 & \\
\hline & understanding and willindness & $\mathrm{BP}$ & 1.74 & 1.24 & 2.37 & 1.33 & \\
\hline & to cooperate with stud.with PD & $\mathrm{BS} \times \mathrm{BP}$ & 10.27 & 7.70 & 15.94 & 6.71 & $.000 *$ \\
\hline 7 & Schools principals & BS & 5.19 & 1.19 & 5.33 & 1.67 & \\
\hline & support inclusion & $\mathrm{BP}$ & 1.51 & 1.33 & 2.05 & 1.49 & \\
\hline & & $\mathrm{BS} \times \mathrm{BP}$ & 8.48 & 7.73 & 12.30 & 8.29 & $.020 *$ \\
\hline 8 & Families of students & $\mathrm{BS}$ & 5.93 & 0.96 & 5.60 & 1.09 & \\
\hline & with disabilities & $\mathrm{BP}$ & 1.80 & 1.27 & 2.18 & 1.45 & \\
\hline & show cooperation & $\mathrm{BS} \times \mathrm{BP}$ & 11.29 & 8.38 & 13.35 & 7.26 & .191 \\
\hline & ontrol Beliefs & $\mathrm{BS} \times \mathrm{BP}$ & 39.48 & 34.38 & 56.37 & 31.46 & $.012 *$ \\
\hline
\end{tabular}

Note. Belief strength (BS) statements range from 1 to 7 (strongly disagree to strongly agree). Belief power (BP) statements score from -3 to +3 (much more difficult to much easier). BS x BP scores range from -21 to $+21 .{ }^{*} p<.05$, $* * p<.01$ 


\section{DISCUSSION}

A major stride in many countries regarding the education system has been noted primarily regarding the area of inclusion. This is of particular importance when discussing physical education classes. Previous studies have shown to be favourable towards inclusion (O'Brien et al., 2009). Developing inclusive practices have proven to be a challenge as many factors come into play, acting as obstacles. Major barriers to inclusive practices are teacher's attitudes and approaches to inclusion. Attitudes towards inclusion in PE affect the smooth and

successful progression of inclusion and the positive outcomes. According to previous studies (Bartonova, Kudlacek \& Bressan, 2007; Martin \& Kudlacek, 2010) participants generally held positive attitudes with respect to having students with physical disabilities in their classes. No significant differences were found between the various concerns of interest. However, findings in the current study showed that female PE teachers in Cyprus displayed differences towards the negative outcome for including students with physical disabilities within their GPE classes.

Primary focus within this study was the gender differences observed regarding inclusion with a focus on behavioural beliefs, normative beliefs and control beliefs and the differences within. Findings demonstrated that males generally had a greater inclination towards including students with physical disabilities in their general PE classes, in comparison to their female counterparts. This finding is in contradiction to studies mentioned by Kozub and Lienert (2003) in which females had significantly more favorable attitudes. Though the current study found males to have a greater tolerance for inclusion, this finding was not statistically significant. This is the general trend within the literature: inconsistent findings regarding gender differences (Avramidis \& Norwich, 2002; Kozub \& Lienert, 2003). As the primary focus tends to be on inclusion and attitudes in most literature, gender differences may not be addressed appropriately.
Attitudes are a primary influence on one's behaviour. How an individual perceives or approaches a situation will impact the manner in which he or she will respond. This is the basis of the behavioural belief component of TPB. The beliefs and attitudes carried by teachers and parents regarding inclusion not only impact their own response to individuals with PD, they also influence and play a significant part on the development of the attitudes and beliefs of their students. Students with disabilities generally prefer participation in inclusive $\mathrm{PE}$ rather than in segregated settings as it promotes a sense of belonging, skilful participation and sharing in the benefits (Goodwin \& Watkinson, 2000) On the contrary, negative experiences include social isolation, questioned competence and restricted participation (Goodwin \& Watkinson, 2000).

Many studies have shown that students without disabilities can be important to the success of inclusion and that inclusion can be effectively implemented without any negative impact on students (O'Brien et al., 2009). Findings from the current study showed that males generally demonstrate an attitude supporting inclusion; males tend to believe that inclusion will help students without disabilities learn to interact with individuals with PD, will encourage students without disabilities learn to help others, and will also have a positive effect on the development of personalities of students with PD. Though males demonstrated a positive attitude towards inclusion, they tended to believe that the quality of PE lessons would be negatively affected by including individuals with PD into general PE classes. As mentioned previously, these findings were in contrast to those found in females who believed that students without PD will experience discrimination when including individuals with PD in their GPE classes. As with previous studies, the findings were not statistically significant however demonstrate a pattern of gender differences.

The perceived social pressure and estimated response to this pressure is referred 
to the normative belief. This relates to the perception individuals, specifically $\mathrm{PE}$ teachers, may have regarding what is expected of them and how motivated they are to fulfil these expectations. How much teachers are expected to include students with PD in GPE classes and how willing they are in doing so directly impacts the manner in which teachers will approach inclusion and students with PD. Successful implementation of inclusion is strengthened by the combination of teacher and outside support such as an adaptive physical education consultant or peer tutor support system. Davis et al., (as cited in O'Brien et al., 2009) stressed that support personnel can help improve the physical education of students by assisting in social interaction and transfer from one activity to the next, safety, interaction with students, and cooperative learning amongst students and reinforcing instructions for the teachers.

Support from specialist personnel has been shown to be influential in shaping positive teacher attitudes to inclusion. Effective support, both interpersonal and taskrelated, empowers teachers to successfully include PD students within GPE classes and increases teachers' self-efficacy, competence and satisfaction (Kauffman, Lloyd, McGee, 1989; Janney et al., 1995; Center Ward, 1987; Minke et al., 1996 as cited in Avramidis et al., 2002). Gender differences were observed within the current study, where males demonstrated a greater affinity towards accepting the aid of support personnel and a greater willingness to follow-through with the advice and guidelines provided. This finding was statistically significant and although previous literature lacks in gender comparisons in this area, the finding may be based on a cultural trend within Cyprus and should be further examined.

Control belief is the third TBP component examined and is used to determine perceived behavioural control and is a direct predictor of intention. It refers to the factors and circumstances that teachers believe might make inclusion of students with PD more difficult or easier (i.e. resources, training, equipment, etc). Most literature does not address the gender differences observed within this area of study. As has been the general trend within this study, the findings significantly favour males. The findings, statistically significant, indicate that males believe that the principles in most schools will offer the support needed and that the schools have the appropriate equipment necessary to make inclusion easier. Males also believe that students will demonstrate a greater understanding and willingness to cooperate and work with students with PD.

Teachers will generally feel apprehensive when including students with PD within their classrooms and may even express some understandable concerns. Of the main concerns (personal, management, consequence and collaboration), management has been reported as the most important (Leinert, Sherrill, \& Myers, 2001). The responsibilities of a teacher on a daily basis may be rather demanding without having the challenge of working with students with PD. Inclusion has been viewed from both a positive and negative perspective. On the positive side, teachers believe that the idea of inclusion was good however the implementation of it is met with many barriers. The inability to give the time and individual attention to students with PD has been found to be a recurring concern for many teachers (Hodge, Ammah, Casebolt, Lamaster \& O'Sullivan, 2004). Lack of professional preparation, lack of equipment and programming curriculum have also been found to impact teachers' attitudes towards inclusion and has been shown to be directly linked to burnout in physical education (Lieberman, Houston-Wilson \& Kozub, 2002 Fejgin, Talmor, \& Erlich, 2005).

Inclusion has been found to be quite effective when implemented successfully and with the appropriate support personnel. However, it is vital to address the attitudes and beliefs held by teachers in order to ensure a successful program. Students with PD have demonstrated greater personal growth when placed in inclusive classes yet the risks should be noted so as not to isolate them (O'Brien et 
al., 2009). The current study attempted to address the gender differences that are present within the area of inclusion; how males' and females' attitudes impact the inclusion of students with PD. Further research should be conducted examining the gender differences in detail as it is a vital part in the advancement of helping students with PD.

\section{REFERENCES}

Ajzen, I. (1991). The theory of planned behavior. Organizational Behavior and Human Decision Processes, 50, 179-211.

Ajzen, I. \& Driver B.L. (1992). Application of the theory of planned behavior to leisure choice. Journal of Leisure Research, 24, 207-224.

Angelides, P., Stylianou, T., \& Gibbs, P. (2006).Preparing teachers for inclusive education in Cyprus. Teaching and Teacher Education, 22, 513-522.

Avramidis, E., \& Kalyva, E. (2007). The influence of teaching experience and professional development on Greek teachers' attitudes towards inclusion. European Journal of Special Needs Education, 22 (4), 367 - 389.

Avramidis, E., \& Norwich, B. (2002). Teachers' attitudes towards integration/inclusion: a review of the literature. Eur. J. of Special Needs Education, 17(2), 129-147.

Bartonova, R., Kudlacek, M., \&Bressan, L. (2007). Attitudes of future physical educators toward teaching children with disabilities in physical education in the Republic of South Africa. Acta Univ. Palacki.Olomuc., Gymn. 37(4), 69-75.

Batsiou, S., Bebetsos, E., Panteli, P., \&

Antoniou, P. (2006). Attitudes and intention of Greek and Cypriot primary education teachers towards teaching pupils with special educational needs in mainstream schools. International Journal of Inclusive Education, 12, 201-219.

Block, M. E. (1999). Did We Jump on the Wrong Bandwagon? Problems with Inclusion in Physical Education. Palaestra, 15 (3), 30-36.
Block, M.E., \& Rizzo, T.L. (1995). Attitudes and attributes of physical educators associated with teaching individuals with severe and profound disabilities. Journal of The Association for Persons with Severe Handicaps, 20(1), 80-87.

Block, M.E., \& Vogler, E.W. (1994). Inclusion in regular physical education: The research base. Journal of Physical Education, Recreation, and Dance, 65(1), 40-44.

DePauw, K.P., \& Goc Karp, G. (1990). Attitudes of selected college students toward including disabled individuals in integrated settings. In G. Doll-Tepper, C. Dahms, B. Doll, \& H. Von Selzam (Eds.), Adapted Physical Activity (pp. 149-158). Berlin.

Doulkeridou, A., Evaggelinou, C., Mouratidou, A.,Koidou, E., Panagiotou, A., \& Kudlacek, M. (2010). Attitudes of Greek Physical Education Teachers toward inclusion of students with disabilities in Physical Education classes.

International Journal of Special Education. 26(1), 1-11.

Doulkeridou, A, Evaggelinou, C., \& Kudlacek, M. (2010). Components of attitudes towards inclusion of students with physical disabilities in Physical Education in the "ATIPDPE-GR" instrument/scale for Greek Physical Educators. Acta Univ. Palacki.Olomuc., Gymn., 40(4), 63-68.

Downs, P., \& Williams, T. (1994).Student attitudes toward integration of people with disabilities in activity settings. Adapted Physical Activity Quarterly, 11, 32-43.

Fejgin, N., Talmor, R., \& Erlich, I. (2005). Inclusion and burnout in physical education. European Physical Education Review, 2(1), 29-50.

Folsom-Meek, S.L., \& Rizzo, T.L. (2002).Validating the physical educators' attitude toward teaching individuals with disabilities III (PEATID III) survey for future professionals. Adapted Physical Activity Quarterly, 19, 141-154. 
Goodwin, D.L., \& Watkinson, E.J. (2000). Inclusive Physical Education from the Perspective of Students With Physical Disabilities. Adapted Physical Activity Quarterly, 17, 144-160.

Hall, A. (1994). A descriptive assessment of social relationship in integrated classrooms. Journal of Association of Persons with Severe Handicaps, 19, 103111.

Hardman, K. (2008). The Situation of Physical Education in Schools: A European Perspective. Human Movement, 9(1), 1899-1955.

Hodge, S. R., Ammah, J. O.A., Casebolt, K., LaMaster, K., \& O'Sullivan, M. (2000).Analysis of inclusion practice in physical education. Unpublished observational behavioral instrument. The OhioStateUniversity, Columbus, OH.In Ammah, J.O.A., \& Hodge, S.R. (2005).

Hodge, S.R., Ammah, J.O.A., Casebolt, K., Lamaster, K., \& O'Sullivan, M. (2004).

High School General Physical Education Teachers' Behaviors and Beliefs Associated with Inclusion. Sport, Education and Society, 9(3), 395-419.

Hodge, S., \&Jansma, P. (1999). Effect of contact time and location of practicum experiences on attitudes of physical education majors. Adapted Physical Activity Quarterly, 16, 48-63.

Hutzler, Y., Zach, S., \& Gafni, O. (2005). Physical education students' attitudes and self-efficacy towards the participation of children with special needs in regular classes. European Journal of Special Needs Education, 20(3), 309-327.

Indiana Protection and Advocacy Services.(n.d.). Retrieved March 12, 2010, from Official Website of State of Indiana: http://www.in.gov

Kowalski, E.M., \& Rizzo, T.L. (1996).Factors influencing preservice student attitudes toward individuals with disabilities. Adapted Physical Activity Quarterly, 13, 180-196.

Kozub, F.M., \& Lienert, C. (2003). Attitudes toward teaching children with disabilities: Review of literature and research paradigm. Adapted Physical Activity Quarterly, 20, 323-346.

Kozub, F., \& Porretta, ZD. (1988). Interscholastic coaches' attitudes toward integration of adolescents with disabilities. Adapted Physical Activity Quarterly, 15, 328-344.

Kudlacek, M. (2008). Inclusion of children with physical disabilities in physical education, recreation and sport. Palacky University, Olomouc, 1st edition.

Kudlacek, M., Valkova, H., Sherrill, C., Myers, B., \& French, R. (2002).An inclusion instrument based on planned behavior theory for prospective Czech physical educators. Adapted Physical Activity Quarterly, 19, 280-299.

Kudlacek, M. (2001). An attitude toward inclusion instrument based on the theory of planned behavior for prospective Czech physical educators. Unpublished doctoral dissertation, Texas Woman's University, Denton.

Kudlacek, M. (2009). European Inclusive Physical Education Training. Retrieved march14, 2010, from European Inclusive Physical Education Training web site: http://eipet.eu

Lieber, J., Capell, K., Sandall, S., Wolfberg, P., Horn, E., \&Bechman, P. (1988). Inclusive preschool programs: teacher beliefs and practices. Early Childhood Research Quarterly, 13, 87-105.

Lienert, C., Sherrill, C., \& Myers, B. (2001). Physical Educator's Concerns About Integrating Children With Disabilities: A Cross-Cultural Comparison. Adapted Physical Activity Quarterly, 18, 1-17.

Lieberman, L.J., Houston-Wilson, C., \& Kozub, F.M. (2002). Perceived Barriers to Including Students with Visual Impairments in General Physical Education. Adapted Physical Activity Quarterly, 19, 364-377.

Lieberman, L. J., James, A. R., \& Ludwa, N. (2004).The impact of inclusion in general physical education for all students. Journal of Physical education, Recreation \& Dance, 75 (5), 37-41. 
Martin, K., \& Kudlacek, M. (2010). Attitudes of pre-service teachers in an Australian university towards inclusion of students with physical disabilities in general physical education programs. European Journal of Adapted Physical Activity, 3(1), 30-48.

Meegan, S. \& MacPhail, A. (2006) Irish physical educators' attitude toward teaching students with special educational needs, European Physical Education Review, 12(1), 75-97.

Ministry of education and culture (1996). Bulletin of information of Special Education, 1988 - 1996 (Online) http://www.moec.gov.cy/eidiki/.

Ministry of education and culture (2001). PL $3497 / 2001$ which is related to the education of children with SEN in public schools

Online http://www.moec.gov.cy/eidiki/.

Ministry of education and culture (2010a). National curriculum for physical education.

Online) http://www.paideia.org.cy/upload/analytik a_programmata_2010/19.fisikiagogi.pdf

Ministry of education and culture (2010b). Special education. (Online) http://www.moec.gov.cy/eidiki/.

Mrug, S. \& Wallander, L.J. (2002). SelfConcept of Young People with Physical Disabilities: does integration play a role? International Journal of Disability, Development and Education, 49(3), 267274.

Obrusnikova, I., Block, M.E., \&Válková, H. (2003). Impact of inclusion in GPE on students without disabilities. Adapted Physical Activity Quarterly, 20, 230-245.

O'Brien, D., Kudlacek, M., \& Howe, P.D. (2009). A contemporary review of English language on inclusion of students with disabilities in physical education: A European perspective. European Journal of Adapted Physical Activity, 2(1), 46-61.

Panagiotou, A., Evaggelinou, C., Doulkeridou, A., Mouratidou, K., \& Koidou, K (2008). Attitudes of 5th and 6th grade Greek students toward the inclusion of children with disabilities in physical education classes after a Paralympic Education program. European Journal of Adapted Physical Activity, 1(2), 31-43.

Papadopoulou, D., Kokaridas, D., Papanikolaou, Z., \& Patsiaouras, A. (2004). Attitudes of Greek physical education teachers toward inclusion of students with disabilities. International Journal of Special Education, 19(2), 104111.

Peck, C., Carlson, P., \&Helmstetter, E. (1992). Parent and teacher perceptions of outcomes for typically developing children enrolled in integrated early childhood programs: a state-wide survey. Journal of Early Intervention, 16, 53-63.

Rizzo, T.R., \& Kirkendall, D.R. (1995). Teaching Students with mild disabilities: What affects attitudes of future physical educators? Adapted Physical Activity Quarterly, 12, 205-216.

Rizzo, T.L., \&Vispoel, W.P. (1991).Physical educators' attributes and attitudes toward teaching students with handicaps. Adapted Physical Activity Quarterly, 8, 4-11.

Rizzo, T.R., \& Wright, R.G. (1988).Physical educators' attitudes toward teaching students with handicaps. Mental Retardation, 26, 307-309.

Romer, L., \&Haring, N. (1994). 'The social participation of students with deafblindness in educational settings', Education and Training in Mental Retardation and Developmental Disabilities, 29, 134-144.

Salisbury, C., Gallucci, C., Palombaro, M., \& Peck, C. (1995). Strategies that promote social relations among elementary students with and without severe disabilities in inclusive schools.Exceptional Children, 62, 125137.

Sherrill, C. (2004). Adapted Physical Activity, Recreation and Sport: Crossdisciplinaryand Lifespan (6th ed.). 
New York, NY: McGraw-Hill Companies.

Stein, J. U. (1994). Total inclusion or least restrictive environment Journal of Physical education, Recreation \& Dance, 65 (9), 21-25.

Triandis, H. (1971). Attitude and attitude change. New York:Wiley \& Sons.

Tripp, A., French, R., \& Sherrill, C. (1995). Contact theory and attitudes of children in physical education programs towards peers with disabilities. Adapted Physical Activity Quarterly, 12, 323-332.

Vaporidi, I., Kokaridas, D. \& Krommidas, C. (2005).Attitudes of Physical Education

Teachers toward the Inclusion of Students with Disabilities in Typical Classes. Inquiries in Sport \& Physical Education, 3 (1), 40 - 47. (In Greek)

Xafopoulos, G., Kudlaček,M., \&Evaggelinou, C. (2009). Effect of the intervention program "Paralympic School Day"on attitudes of children attending international school towards inclusion of students with disabilities. Acta Univ. Palacki.Olomuc., Gymn., 39(4), 63-71.

Corresponding author's e-mail address: ifournidou@googlemail.com martin.kudlacek@upol.cz evaggeli@phed-sr.auth.gr

\section{(Abstract) \\ EINSTELLUNGEN VON SPORTLEHRENDEN GEGENÜBER DEM UNTERRICHTEN VON KINDERN MIT KÖRPERLICHEN BEHINDERUNGEN IN REGELKLASSEN IN ZYPERN}

Im Laufe der letzten zwei Jahrzehnte rückte die Idee der Inklusion von Schüler(inne)n mit sonderpädagogischem Förderbedarf $(\mathrm{SspF})$ in allgemeinen Schulen zunehmend in den Fokus der inklusiven Erziehung in Zypern. Das Ziel dieser Studie war es, die Einstellungen und Einstellungsprädiktoren von Bewegungserzieher(inne)n in zypriotischen Sekundarschulen gegenüber der Inklusion von Schüler(inne)n mit körperlichen Behinderungen im regulären Sportunterricht zu ermitteln. Es wurde die ins Griechische übersetzte Version des ATIPDPG-GRFragebogens (Doulkeridou, Evaggelinou \& Kudlacek, 2010), ursprünglich entwickelt von Kudlacek, Valkova, Sherrill, Myers und French (2002), verwendet. Dieses Instrument wurde auf der Basis der Theorie des geplanten Verhaltens (TPB) von Ajzen (1991) entwickelt. Die Ergebnisse der stufenweisen multiplen Regressionsanalyse ergaben für $\mathrm{R}^{2}=.547$ und zeigten damit den Prozentsatz der Variabilität der Varianz der Intention, die durch die Einstellung gegenüber dem Verhalten und der wahrgenommenen Verhaltenskontrolle erklärt wird. Die wahrgenommene Verhaltenskontrolle hatte die stärkste Korrelation mit der Absicht Schüler(innen) mit körperlichen Behinderungen in den allgemeinen Sportunterricht $\mathrm{zu}$ inkludieren mit $p<0.01$. Die Subskala Einstellung gegenüber Verhalten hatte die zweitstärkste Korrelation mit der Absicht, Schüler(innen) mit körperlichen Behinderungen in den allgemeinen Sportunterricht zu inkludieren mit $p<0.05$. Weiters zeigten die Ergebnisse keine signifikanten Unterschiede zwischen Frauen und Männern hinsichtlich der Absicht für Inklusion.

SCHLÜSSELWÖRTER: Einstellungen, Inklusion, Bewegungserzieher(innen), Sportunterricht, Schüler(innen) mit Behinderung und sonderpädagogischem Förderbedarf, körperliche Behinderung 


\section{(Résumé) \\ ATTITUDES DES ENSEIGNANTS D'EDUCATION PHYSIQUE ENVERS DES ENFANTS ATTEINTS DE HANDICAPS MOTEURS EN MILIEU SCOLAIRE GENERAL EN CHYPRE}

Durant ces deux dernières décennies, l'idée d'inclure des enfants en situation de handicap moteur en milieu scolaire général est devenue une priorité en Chypre. Le but de cette étude était d'observer et évaluer les attitudes des enseignants d'éducation physique envers l'inclusion d'enfants handicapés moteurs en milieu scolaire général. La version Grecque traduite du questionnaire ATIPDPE-GR (Doulkeridou, Evaggelinou \& Kudlacek, 2010) développé à l'origine par Kudlacek, Valkova, Sherrill, Myers and French (2002) a été utilisée. Ce questionnaire est basé sur "Theory of Planned Behavior" (TPB) de Ajzen (1991). Les resultats d'une regression linéaire multiple indiquent un coefficient de détermination ( $\mathrm{R}$ square) égal à 0,547 démontrant la variabilité de la variable d'intention expliquée par l'attitude comportementale et le control comportemental perçu. Le control comportemental perçu a la plus forte et significative corrélation $(p<0.05)$ sur l'intention d'inclure des élèves ayant un handicap moteur en milieu scolaire général. De plus, aucune différence significative n'a été démontré entre les garçons et les filles dans l'intention d'inclusion.

MOTS CLES : attitudes, inclusion, éducation physique, enseignant d'éducation physique, enfants handicapés moteurs, handicap physique

\section{(Аннотацця) \\ ОТНОШЕНИЕ ПЕДАГОГОВ ПО ФИЗИЧЕСКОЙ КУЛЬТУРЕ К ОБУЧЕНИЮ ДЕТЕЙ С ОГРАНИЧЕННЫМИ ФИЗИЧЕСКИМИ ВОЗМОЖНОСТЯМИ В СИСТЕМЕ ОБЩЕГО ФИЗИЧЕСКОГО ВОСПИТАНИЯ НА КИПРЕ.}

За последние два десятилетия идея включения учащихся с особыми образовательными потребностями в общеобразовательных школах становится все более актуальной для инклюзивного образования на Кипре. Целью данного исследования было выявление отношения учителей физкультуры кипрской средней школы к включению учащихся с ограниченными физическими возможностями в общие занятия по физическому воспитанию. Был использован вопросник, переведенный с греческого, ATIPDPE-GR (Doulkeridou, Evaggelinou \& Kudlacek, 2010) изначально разработанный Kudlacek, Вальковой, Шеррилл, Майерс и Френч (2002).

Прибор разработан на основе "Теории запланированного поведения" по Айзенку (1991). Результаты поэтапной множественной регрессии (отображаемые в индикаторе «R Square») принимают значения до 0,547, что показывает процент изменчивости дисперсии намерений включить студентов с ограниченными физическими возможностями в систему общего физического воспитания и объясняется двумя показателями: «Отношением к Поведению» и «Воспринимаемым Поведенческим Контролем». «Воспринимаемый Поведенческий Контроль» при $\mathrm{p}<0.01$ означал сильную корреляцию с намерением включить студентов с ограниченными физическими возможностями в систему общего физического воспитания. Другой показатель «Отношение к Поведению» был вторым по силе корреляции при р <0,05. Кроме того результаты показали, что существенного различия между женщинами и мужчинами в этом отношении нет.

КЛЮЧЕВЫЕ СЛОВА: отночения, включение, педагоги по ФК, физическое воспитание, студенты с ограниченными возможностями и особыми потребностями, инвалидность

(Resumen) 


\section{LAS ACTITUDES DE LOS PROFESORES DE EDUCACIÓN FÍSICA EN ACTIVO HACIA LOS NIÑOS CON DISCAPACIDAD FÍSICA EN LAS CLASES DE EDUCACIÓN FÍSICA GENERAL DE CHIPRE}

Durante las últimas dos décadas el concepto de la inclusión de alumnos con necesidades educativas especiales (NEE) en las escuelas normalizadas en Chipre tiene cada vez más un enfoque hacia la educación inclusiva. El objetivo de este estudio fue identificar las actitudes y los predictores de dichas actitudes de los profesores chipriotas de educación física en activo en secundaria hacia la inclusión de estudiantes con discapacidades físicas en las clases de educación física general. Fue utilizada la versión griega traducida del cuestionario ATIPDPE-GR (Doulkeridou, Evaggelinou y Kudlacek, 2010) desarrollado originalmente por Kudlacek, Valkova, Sherrill, Myers y French (2002). El instrumento fue diseñado en base a la "Teoría del comportamiento planificado" (TCP) por Ajzen (1991). Los resultados de la regresión múltiple por pasos indican una $\mathrm{R}$ cuadrado de 0,547, mostrando el porcentaje de la variabilidad de la varianza explicada por el test utilizado. El control del comportamiento percibido tuvo una fuerte correlación en la intención de incluir a los estudiantes con discapacidad física en la educación física general, con $p<0,01$. La subescala Actitud hacia el Comportamiento tuvo la segunda correlación más fuerte en la intención de incluir a los estudiantes con discapacidad física en la educación física general, con $p<0,05$. Además, los resultados no muestran diferencias significativas entre mujeres y hombres hacia la intención para la inclusión.

PALABRAS CLAVE: actitudes, inclusión, profesores de educación fisica, educación fisica, estudiantes con discapacidad y necesidades educativas especiales, discapacidad fisica.

\section{(Resumo) \\ ATITUDES DOS PROFESSORES DE EDUCAÇÃO FÍSICA FACE AO ENSINO DE CRIANÇAS COM DEFICIÊNCIAS FÍSICAS NAS AULAS DE EDUCAÇÃO FÍSICA NO CHIPRE}

Durante as duas últimas décadas, a ideia de inclusão de alunos com necessidades educativas especiais (NEE) nas escolas do ensino regular tornou-se cada vez mais o foco da educação inclusiva no Chipre. O objetivo deste estudo foi identificar as atitudes, e os preditores de atitudes, de professores cipriotas de educação física do ensino secundário face à inclusão de alunos com deficiências físicas nas aulas de educação física. Foi utilizada a versão grega traduzida do questionário ATIPDPE-GR (Doulkeridou, Evaggelinou \& Kudlacek, 2010) originalmente desenvolvido por Kudlacek, Valkova, Sherrill, Myers e French (2002). O instrumento foi desenvolvido com base na "Teoria do Comportamento Planejado" (TPB) por Ajzen (1991). Os resultados da regressão múltipla indicaram um $\mathrm{R}^{2}$ de 0,547 que mostra a percentagem de variabilidade da variância da intenção explicada pela atitude em relação ao comportamento e pelo controlo comportamental percebido. $\mathrm{O}$ controlo comportamental percebido teve a correlação mais forte na intenção para incluir alunos com deficiências físicas na aula Educação Física, com $p$ $<0,01$. A subescala da atitude face ao comportamento teve a segunda correlação mais forte na intenção de incluir alunos com deficiências físicas na Educação Física, com $p<0,05$. Além disso os resultados não mostram diferenças significativas entre homens e mulheres face à intenção de inclusão.

PALAVRAS-CHAVE: atitudes, inclusão, professores de educação física, educação física, alunos com deficiências e NEE; deficiência fisica 